\title{
Concrete Containing Marginal Aggregates for Use in
}

\section{Concrete Pavement}

\author{
Patrick Amoah Bekoe ${ }^{1}$ and Mang Tia ${ }^{2}$ \\ 1. Department of Feeder Roads, Ministry of Roads and Highways, Koforidua P.O.Box 2588, Ghana \\ 2. Department of Civil and Coastal Engineering, University of Florida, Gainesville P.O.Box 116580, USA
}

\begin{abstract}
The study presented an analysis accessing the feasibility of using concrete containing marginal aggregates in concrete pavement slabs. The physical properties of aggregates were first determined and concrete was produced from them. Marginal aggregates were found to have higher fines, absorption, soundness loss, micro-Deval abrasion loss, LA (Los Angeles) abrasion loss and lower specific gravity and unit weight when compared with standard aggregates. Workability of concrete containing marginal aggregate was found to be similar to concrete containing normal aggregates when Shilstone mix design method was used to optimize the concrete mixes. The compressive strength, splitting tensile, flexural strength and modulus of elasticity of concrete containing marginal aggregates were determined and found to be generally lower than concrete containing standard aggregates. A typical concrete pavement in Florida was modeled in FEACONSIV (finite element analysis of concrete slab) software developed at the University of Florida. Laboratory determined mechanical and thermal properties of concrete were inputted in FEACONS IV and analyzed for maximum induced stresses. Critical stress to strength ratios, i.e., ratio between maximum computed stresses obtained from FEACONS IV to modulus of rupture (strength) of concrete, was used as evaluation criterion for different concrete pavement mixes. It was found that, in general, concrete containing marginal aggregates have higher stress to strength ratios as compared with concrete containing standard aggregates.
\end{abstract}

Key words: Marginal aggregates, concrete, pavement, stress to strength ratio, FEACONS.

\section{Introduction}

Concrete is generally thought of as having three components, i.e., aggregate phase, hydrated cement paste and ITZ (interfacial transitional zone) between the hydrated cement paste and the aggregate phase. The aggregate phase is the stronger of the two phases and is predominantly responsible for unit weight, elastic modulus and dimensional stability of concrete. For normal concrete, the aggregate phase mostly has no influence on strength except in the case of highly porous and weak aggregates such as pumice [1]. In view of the above, the strength of aggregate is mostly not taken into consideration when producing normal concrete. However, due to increasing depletion of good quality aggregates, weaker aggregates are now

Corresponding author: Patrick Amoah Bekoe, Ph.D., research fields: materials and pavement engineering, transportation economics and transportation asset management. E-mail: pabekoe@gmail.com. considered to be used for some concrete application, and thus, the need to examine closely the effect of aggregate strength on mechanical and durability properties of concrete produced from them. These weaker aggregates are mostly considered as marginal or borderline aggregates and do not meet current standards and specifications, and in cases where they are allowed, they are used for concrete applications with very low strength. Key among these weak aggregates is natural aggregates that do not meet current standards and specifications.

The classification of aggregates as marginal or borderline is dependent on the standard of comparison. In the US, most aggregates for use in DOT (Department of Transportation) applications must either satisfy ASTM (American Society for Testing and Materials), AASHTO (American Association of State Highway and Transportation Officials), or specific tailored standards, as stipulated in various 
states standard specifications. Thus, an aggregate is considered as marginal when it does not meet the aforementioned standards. Usually, marginal or borderline aggregates fail to meet requirements of gradation, LA (Los Angeles) abrasion loss, soundness loss, shell content, specific gravity, absorption, etc.. These marginal aggregates are generally considered to be weaker, and thus require special attention before incorporating them into concrete mixes.

This paper first compares properties of concrete obtained from marginal aggregates with those obtained from standard aggregates. It proceeds with using the mechanical properties of these concrete as input in a finite element analysis software to predict the possible performance of the concretes if they were used as slabs in concrete pavement.

\section{Research Significance}

Past research into effect of marginal aggregates on performance of concrete has been limited [2-4]. Furthermore, there is a burgeoning need for the feasibility of using marginal aggregates in most states. If this objective is realized, there will be a potential increase in aggregate mines that were hitherto not accredited to supply aggregates for certain DOT works. Also, existing aggregate mines may increase their production lines hence a general increase in aggregate supply within the United States.

\section{Materials and Test Method}

This research was conducted in the state of Florida and aggregates were selected with assistance from FDOT (Florida Department of Transportation) personnel. Two currently approved aggregate sources (standard aggregates) and eight non approved sources (marginal aggregates) were identified and used for the research. Table 1 shows a list of different aggregate sources and nomenclature used to identify them in this paper. Sieve analysis was conducted on aggregates in accordance with ASTM C136 [5]. The percentage of material finer than $75 \mu \mathrm{m}$ sieve was determined in accordance with ASTM C117 [6]. Table 2 shows aggregate gradation. It must be noted that modified Miami oolite (S1) and modified Fort Myers (S2) aggregates were artificially created by adding pulverized fines passing the No. 200 sieve to produce aggregates with a total percentage passing the No. 200 sieve of $5 \%$ and $8 \%$, respectively. From the gradation, it is observed that most of the aggregates failed to meet ASTM C33 [7] specification especially on the finer sieves. Specifically, Aggregates S3, S4, S5, S6, S7, S8, and S10 all failed to meet ASTM C33 [7] requirement of $0 \%-5 \%$ on sieve size $2.36 \mathrm{~mm}$. Specific gravity and absorption of aggregates were determined in accordance with ASTM C127 [8]. From Table 3, it can be observed that absorptions of marginal aggregates

Table 1 Identification of aggregate sources.

\begin{tabular}{lllll}
\hline Aggregate I.D. & FDOT mine \# & Nomenclature & Aggregate properties not meeting current standards & Aggregate type \\
\hline S1 & 87089 & Miami oolite & & Standard \\
S2 & 12260 & $\begin{array}{l}\text { Fort Myers } \\
\text { Modified Miami } \\
\text { oolite }\end{array}$ & $\begin{array}{l}\text { Miami oolite with addition of pulverized fines to produce a } \\
\text { total of } 8 \% \text { minus } 200\end{array}$ \\
S3 & 87089 & Modified Fort Myers & $\begin{array}{l}\text { Fort Myers with addition of pulverized fines to produce a } \\
\text { total of 5\% minus } 200\end{array}$ & Marginal \\
S4 & 12260 & Inglis & High minus 200 & Marginal \\
S5 & N/A & Cabbage Grove & High LA abrasion loss & Marginal \\
S6 & 38228 & Ocala & High LA abrasion & Marginal \\
S7 & 36696 & Coral rock & High shell content & Marginal \\
S8 & 01011 & Weber south & High shell content & Marginal \\
S9 & N/A & Brooksville & High LA abrasion loss & Marginal \\
S10 & 08012 & & &
\end{tabular}


Table 2 Results of sieve analysis.

\begin{tabular}{|c|c|c|c|c|c|c|c|c|c|c|c|}
\hline \multirow{3}{*}{$\begin{array}{l}\text { Sieve size } \\
(\mathrm{mm})\end{array}$} & \multirow{3}{*}{$\begin{array}{l}\text { ASTM C } 33 \text { gradation } \\
\text { requirement }\end{array}$} & \multicolumn{10}{|c|}{ Aggregate source } \\
\hline & & $\mathrm{S} 1$ & S2 & S3 & $\mathrm{S} 4$ & S5 & S6 & S7 & S8 & S9 & S10 \\
\hline & & \multicolumn{10}{|c|}{ Percentage passing (\%) } \\
\hline 37.50 & 100 & 100 & 100 & 100 & 100 & 100 & 100 & 100 & 100 & 100 & 100 \\
\hline 25.00 & $95-100$ & 100 & 100 & 100 & 100 & 96 & 98 & 93 & 100 & 100 & 99 \\
\hline 12.50 & $25-60$ & 59 & 30 & 60 & 35 & 48 & 35 & 31 & 66 & 43 & 71 \\
\hline 4.75 & $0-10$ & 7 & 3 & 10 & 9 & 11 & 6 & 7 & 8 & 3 & 22 \\
\hline 2.36 & $0-5$ & 3 & 2 & 6 & 9 & 8 & 6 & 6 & 6 & 2 & 17 \\
\hline Minus $75 \mu \mathrm{m}$ & $3.00 *$ & 2.20 & 0.98 & 5.00 & 8.00 & 3.98 & 3.36 & 4.08 & 2.74 & 0.85 & 9.22 \\
\hline
\end{tabular}

*Concrete subject to abrasion, all other concrete is 5.0\%. In the case of manufactured sand, if the material finer than the $75 \mu \mathrm{m}$ sieve consists of the dust of fracture, essentially free of clay of shale, these limits are permitted to be increased to $5 \%$ to $7 \%$, respectively.

Table 3 Specific gravities and absorption of aggregates.

\begin{tabular}{lllll}
\hline Aggregate source & Bulk specific gravity (dry) & $\begin{array}{l}\text { Bulk specific gravity (SSD } \\
\text { (saturated surface dry)) }\end{array}$ & Apparent specific gravity & Absorption (\%) \\
\hline S1 & 2.35 & 2.45 & 2.63 & 4.54 \\
S2 & 2.39 & 2.54 & 3.99 \\
S3 & 2.30 & 2.45 & 2.63 & 4.54 \\
S4 & 2.35 & 2.39 & 2.54 & 3.99 \\
S5 & 2.30 & 2.45 & 2.59 & 3.85 \\
S6 & 2.35 & 2.27 & 2.49 & 7.25 \\
S7 & 2.11 & 2.29 & 2.54 & 7.80 \\
S8 & 2.12 & 2.34 & 2.52 & 5.16 \\
S9 & 2.23 & 2.32 & 2.57 & 7.38 \\
S10 & 2.16 & 2.08 & 2.46 & 14.38 \\
\hline
\end{tabular}

Table 4 Unit weight, LA abrasion loss, micro-Deval abrasion loss and sodium soundness loss.

\begin{tabular}{lllll}
\hline Aggregate source & Unit weight $\left(\mathrm{kg} / \mathrm{m}^{3}\right)$ & Los Angeles abrasion loss (\%) & Micro-Deval loss (\%) & Sodium soundness loss (\%) \\
\hline S1 & 1323 & 31 & 26 & 9 \\
S2 & 1368 & 36 & 29 & 13 \\
S3 & 31 & 26 & 9 \\
S4 & 1323 & 36 & 29 & 13 \\
S5 & 42 & 27 & 13 \\
S6 & 1368 & 50 & 38 & 14 \\
S7 & 1441 & 46 & 47 & 20 \\
S8 & 1267 & 40 & 29 & 12 \\
S9 & 1287 & 48 & 32 & 29 \\
S10 & 1264 & 67 & 81 & 38 \\
\hline
\end{tabular}

are generally high. Unit weight, LA abrasion loss, micro-Deval abrasion loss and sodium sulfate soundness loss were also determined in accordance with AASHTO T19 [9], AASHTO T96 [10], AASHTO T327 [11] and AASHTO T104 [12], respectively. Table 4 shows a summary of these results. ASTM C33 [7] recommends an LA abrasion loss of less than $50 \%$, thus, only Aggregate S10 fails to meet this requirement. However, FDOT specification [13] requires the value to be less than $45 \%$, consequently, Aggregates S6, S7, S9 and S10 fail to meet FDOT specification.

\section{Concrete Mix Design}

In view of the unique nature of these marginal aggregates, trial mixes were first made using ACI (American Concrete Institute) mix design method [14]. This resulted in a non-workable mix for concrete 
containing the marginal aggregates. Therefore, the Shilstone method $[15,16]$, which is based on gradation optimization, was employed to optimize the mixes and this resulted in workable mixes. Concretes of different proportions were produced using Shilstone and ACI design methods for marginal and standard aggregates, respectively. Silica sand from FDOT source 71132 was used as fine aggregate. The specific gravity and absorption of fine aggregates were determined in accordance to AASHTO T85 [17] and the results are shown in Tables 5 and 6. Types $\mathrm{A}$ and $\mathrm{D}$ water-reducing admixtures complying with ASTM C494 [18] were added to all mixtures to improve their workability. Table 7 shows details of mix proportions and properties of the fresh concrete produced. After fabricating the different samples in accordance with ASTM C192 [19], fresh concrete was cast, de-molded after $24 \mathrm{~h}$ and cured for 28 days. The tests performed on the hardened concrete are shown in Table 8. Results of the tests on the hardened concrete are shown in Table 9.

\section{Test Results of Aggregate and Fresh Concrete}

\subsection{Aggregate Test Results}

From the results of aggregates testing, the following can be inferred:

Table 5 Specific gravity and water absorption of fine aggregates.

\begin{tabular}{ll}
\hline Property & Fine aggregates \\
\hline SSD specific gravity & 2.63 \\
Dry bulk specific gravity & 2.62 \\
Dry apparent specific gravity & 2.65 \\
Absorption & 0.5 \\
\hline
\end{tabular}

Table 6 Results of sieve analysis on the fine aggregate.

\begin{tabular}{ll}
\hline Sieve size $(\mathrm{mm})$ & Percentage passing fine aggregates $(\%)$ \\
\hline 4.75 & 100 \\
2.36 & 99 \\
1.18 & 91 \\
0.60 & 70 \\
0.30 & 32 \\
0.15 & 5 \\
Fineness modulus & 2.03 \\
\hline
\end{tabular}

Table 7 Concrete mix proportions for concrete containing low cement content.

\begin{tabular}{|c|c|c|c|c|c|c|c|c|c|}
\hline \multirow[b]{2}{*}{$\begin{array}{l}\text { Aggregate } \\
\text { source }\end{array}$} & \multirow[b]{2}{*}{$\begin{array}{l}\text { Water/cement } \\
\text { ratio }(w / c)\end{array}$} & \multicolumn{4}{|c|}{ Mix proportions } & \multicolumn{4}{|c|}{ Properties of fresh concrete } \\
\hline & & $\begin{array}{l}\text { Coarse } \\
\text { aggregate } \\
\left(\mathrm{kg} / \mathrm{m}^{3}\right) \\
\end{array}$ & $\begin{array}{l}\text { Fine } \\
\text { aggregate } \\
\left(\mathrm{kg} / \mathrm{m}^{3}\right) \\
\end{array}$ & $\begin{array}{l}\text { Cement } \\
\left(\mathrm{kg} / \mathrm{m}^{3}\right)\end{array}$ & $\begin{array}{l}\text { Water } \\
\left(\mathrm{kg} / \mathrm{m}^{3}\right)\end{array}$ & $\begin{array}{l}\text { Slump } \\
(\mathrm{mm})\end{array}$ & $\begin{array}{l}\text { Unit weight } \\
\left(\mathrm{kg} / \mathrm{m}^{3}\right)\end{array}$ & $\begin{array}{l}\text { Air } \\
\text { content } \\
(\%) \\
\end{array}$ & $\begin{array}{l}\text { Temperature } \\
\left({ }^{\circ} \mathrm{C}\right)\end{array}$ \\
\hline S1 & 0.6 & 991 & 843 & 279 & 167 & 83 & 2,231 & 3.1 & 24 \\
\hline $\mathrm{S} 2$ & 0.6 & 967 & 838 & 279 & 167 & 76 & 2,229 & 2.4 & 24 \\
\hline S3 & 0.6 & 991 & 843 & 279 & 167 & 44 & 2,213 & 3.7 & 25 \\
\hline S4 & 0.6 & 967 & 838 & 279 & 167 & 57 & 2,216 & 2.7 & 27 \\
\hline S5 & 0.6 & 989 & 843 & 279 & 167 & 51 & 2,227 & 2.9 & 24 \\
\hline S6 & 0.6 & 926 & 806 & 279 & 167 & 51 & 2,167 & 2.9 & 23 \\
\hline S7 & 0.6 & 897 & 876 & 279 & 167 & 32 & 2,168 & 3.8 & 26 \\
\hline S8 & 0.6 & 934 & 830 & 279 & 167 & 44 & 2,224 & 2.4 & 21 \\
\hline S9 & 0.6 & 936 & 818 & 279 & 167 & 114 & 2,172 & 3.0 & 24 \\
\hline $\mathrm{S} 10$ & 0.6 & 806 & 860 & 279 & 167 & 38 & 2,103 & 0.4 & 24 \\
\hline
\end{tabular}

Table 8 Tests performed on the concrete samples.

\begin{tabular}{llll}
\hline Test & Standard & Specimen size & Curing period \\
\hline Compressive strength & ASTM C39 & $100 \mathrm{~m} \times 200 \mathrm{~mm}$ cylinder & 28 days \\
Elastic modulus & ASTM C469 & $100 \mathrm{~m} \times 200 \mathrm{~mm}$ cylinder & 28 days \\
Flexural strength & ASTM C78 & $100 \mathrm{~mm} \times 100 \mathrm{~mm} \times 350 \mathrm{~mm}$ beam 28 days \\
Splitting tensile strength & ASTM C496 & $100 \mathrm{~m} \times 200 \mathrm{~mm}$ cylinder & 28 days \\
\hline
\end{tabular}


Table 9 Hardened concrete properties.

\begin{tabular}{llllll}
\hline Aggregate source & $\begin{array}{l}\text { Compressive } \\
\text { strength }(\mathrm{MPa})\end{array}$ & $\begin{array}{l}\text { Splitting tensile } \\
\text { strength }(\mathrm{MPa})\end{array}$ & $\begin{array}{l}\text { Flexural strength } \\
(\mathrm{MPa})\end{array}$ & $\begin{array}{l}\text { Modulus of elasticity } \\
(\mathrm{GPa})\end{array}$ & Poisson's ratio \\
\hline S1 & 32.54 & 3.03 & 4.62 & 28.35 & 0.24 \\
S2 & 31.65 & 3.17 & 4.52 & 27.20 & 0.27 \\
S3 & 32.06 & 3.10 & 4.65 & 27.62 & 0.25 \\
S4 & 29.65 & 4.90 & 3.93 & 25.70 & 0.26 \\
S5 & 26.27 & 2.69 & 3.72 & 22.68 & 0.22 \\
S6 & 25.03 & 2.93 & 3.69 & 22.45 & 0.27 \\
S7 & 23.99 & 2.55 & 4.48 & 22.75 & 0.27 \\
S8 & 28.68 & 3.34 & 3.52 & 25.51 & 0.25 \\
S9 & 2.48 & 2.83 & 20.95 & 0.22 \\
S10 & 19.03 & 1.90 & & 18.16 & 0.25 \\
\hline
\end{tabular}

Most of the marginal aggregates were finer than standard aggregates. They had higher percentage of materials passing No. 4 and No. 200 sieves.

Marginal aggregates have higher absorption and relatively lower SSD. Their unit weights were comparatively lower than those of standard aggregates.

Marginal aggregates were generally less durable when their LA abrasion loss, micro-Deval abrasion loss and sodium sulfate soundness loss are compared with standard aggregates.

\subsection{Fresh Concrete Test Results}

From the fresh concrete test results, the following findings were made:

Workability of concrete mixes using marginal aggregates was similar to those using standard aggregates, although they had higher percentages of material passing No. 4 and No. 200 sieves. This is attributed partly to use of Shilstone mix design method which allowed for optimization of aggregate gradation.

Unit weight for mixtures containing marginal aggregates was about the same as mixtures containing standard aggregates with the exception of concrete containing Aggregate S10, which had lower unit weight.

Air content for mixtures containing marginal aggregates was about the same as mixtures containing standard aggregates with the exception of concrete containing Aggregate S10, which had lower air content.
5.3 Discussion on Aggregates and Concrete Test Results

Marginal aggregates are generally finer than standard aggregates and, thus, fail ASTM C33 [7] requirements. Moreover, they have higher absorption, lower specific gravity and higher LA abrasion values when compared with standard aggregates. However, when properly designed, concrete produced from marginal aggregates can have similar workability and air content as concrete containing standard aggregates. Compressive strength, splitting tensile, flexural strength and modulus of elasticity of concrete containing marginal aggregates are generally lower than concrete containing standard aggregates.

\section{Evaluation of Potential Performance of Concrete in Pavement}

\subsection{FEACONS Analysis}

FEACONS IV (finite element analysis of concrete slabs version IV) program was used to perform stress analysis. FEACONS IV program was previously developed at the University of Florida for FDOT for analysis of PCC (Portland cement concrete) pavements subjected to load and thermal effects and had demonstrated to be a fairly effective and reliable tool for this type of analysis. Fig. 1 shows the finite element model used to perform stress analysis. The 10 different concrete mixes were analyzed to determine their performance on a typical concrete pavement in Florida. 


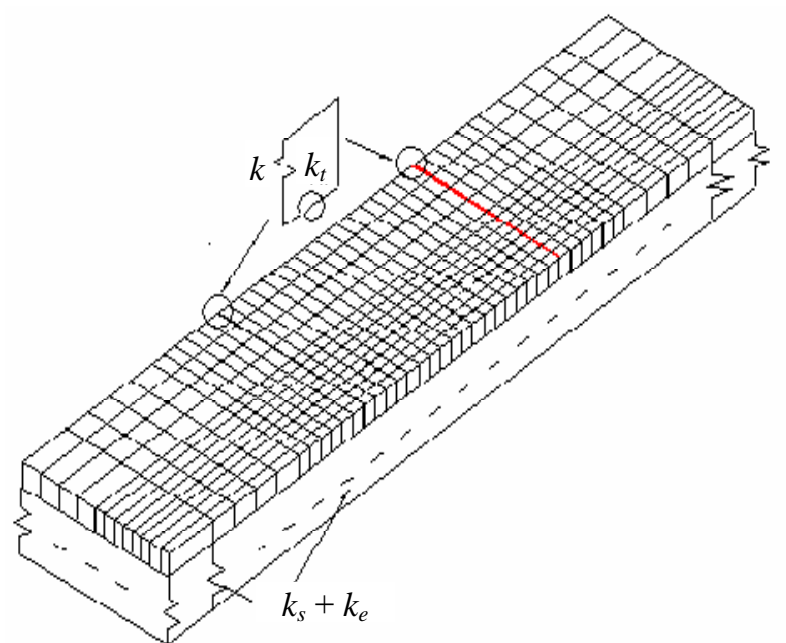

Fig. 1 Finite element model used in FEACONS IV analysis.

The laboratory determined properties in Table 9, i.e., elastic modulus, compressive strength, density and coefficient of thermal expansion, were inputted in the model. Analysis using FEACONS IV model was performed to determine stresses in a $254 \mathrm{~mm}$ thick slab. The analysis was performed to determine maximum stresses in a JPCP (jointed plain concrete pavement) slab loaded with a $98 \mathrm{kN}$ wheel applied at critical loading positions, i.e., slab corner and middle edge as shown in Fig. 2. Temperature differentials of $+6.67^{\circ} \mathrm{C}$, $0{ }^{\circ} \mathrm{C}$ and $-6.67{ }^{\circ} \mathrm{C}$ in concrete slab were used for the analysis. The middle of slab edge is the most critical loading position in day time when temperature differential in the slab is positive, while slab corner is most critical loading position at night when temperature differential is negative. The following parameters were used to model the concrete pavement:

- slab thickness $=254 \mathrm{~mm}$, slab length $=4.57 \mathrm{~m}$, slab width $=3.66 \mathrm{~m}$;

- subgrade modulus, $k_{s}=82 \mathrm{MN} / \mathrm{m}^{3}$, edge stiffness, $k_{e}=207 \mathrm{MN} / \mathrm{m}^{2}$;

- joint linear stiffness, $k_{l}=3447 \mathrm{MN} / \mathrm{m}^{2}$, joint torsion stiffness $k_{t}=4.4 \mathrm{MN}-\mathrm{m} / \mathrm{m}$.

\subsection{Results of Stress Analysis Using FEACONS IV Analysis}

Stress distribution and deflection of pavement due to temperature differential and axle loads are the main output from FEACONS IV. For purpose of this study, focus was placed on stress distribution, typical plots of stress distribution are shown in Figs. 3 and 4. The maximum critical stress was determined for each loading and temperature condition. Thereafter, critical stress to strength ratios, i.e., ratio between maximum critical computed stresses obtained from FEACONS IV to modulus of rupture (strength) of concrete was used as evaluation criterion for different mixes. From fatigue theory, a low stress to strength ratio would indicate a higher number of load repetitions to failure and a better performance potential for concrete pavements in the field. Table 10 shows the critical stress to strength ratios at corner and middle edge of slab with $+6.67^{\circ} \mathrm{C},-6.67{ }^{\circ} \mathrm{C}$ and $0{ }^{\circ} \mathrm{C}$ temperature differentials.

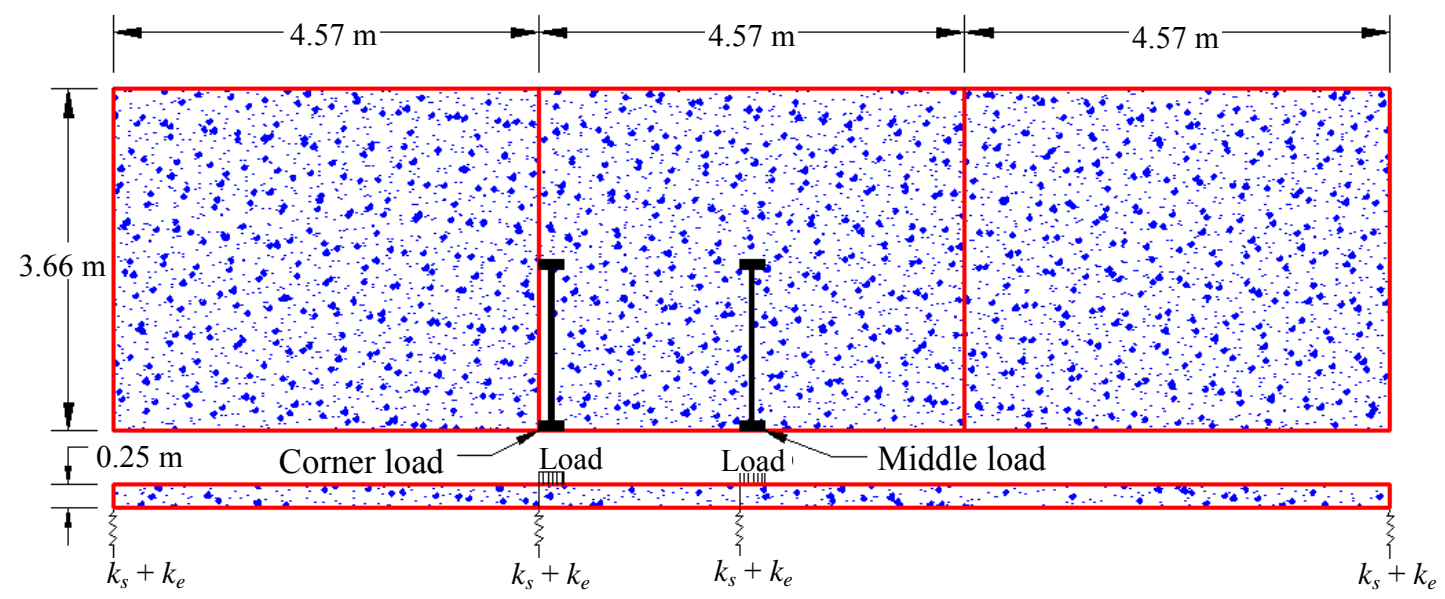

Fig. 2 22-kip wheel load at slab corner and middle edge. 


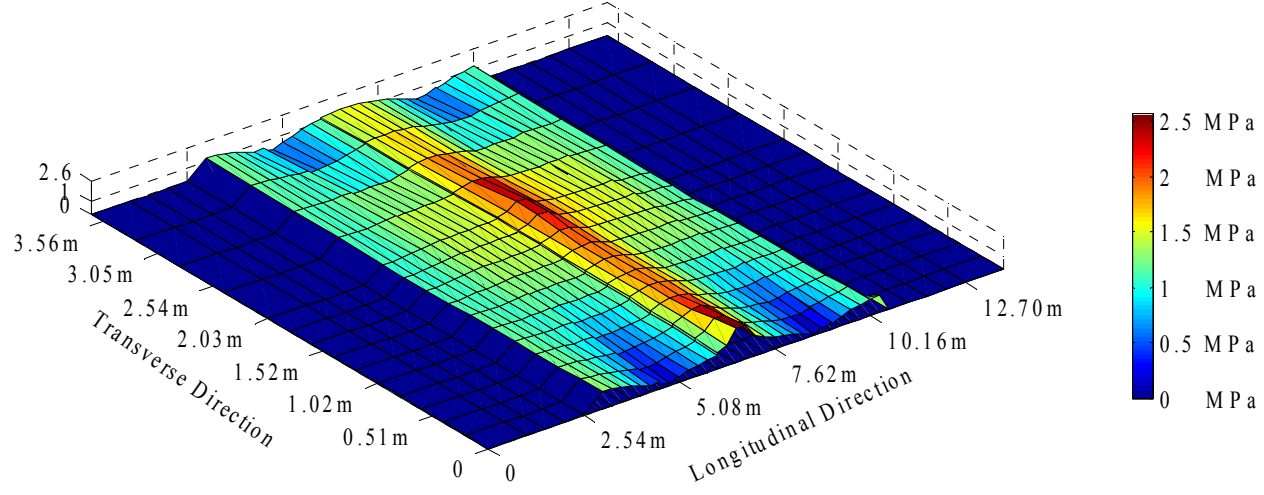

Fig. 3 Typical stress distribution for pavement with positive temperature differential and load at middle edge.

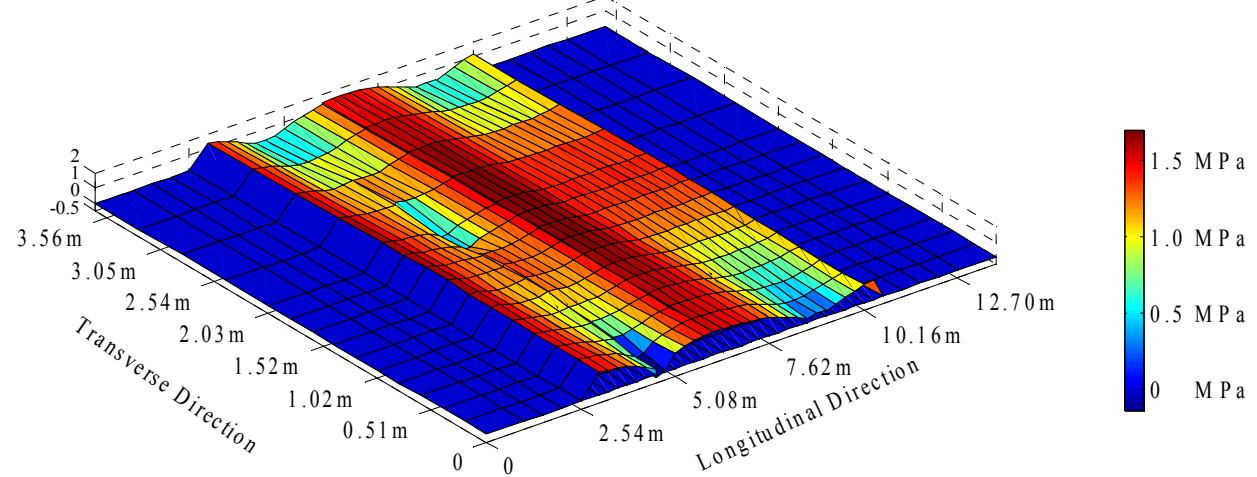

Fig. 4 Typical stress distribution for pavement with negative temperature differential and load at corner edge.

\subsection{Observation on Results of Stress Analysis}

From results presented in Table 10, it can be seen that the most critical loading condition which results in the maximum computed stress was the condition when the $98 \mathrm{kN}$ axle load was applied at middle edge of the slab, and when temperature differential is $+6.67{ }^{\circ} \mathrm{C}$. Thus, the observation of potential performance of the various concrete mixes will be focused mainly on computed stress to strength ratio at this condition. Fig. 5 shows a plot of concrete containing different sources against stress to strength ratios.

From Table 10, it is also observed that critical stress-strength ratios of marginal aggregates are higher than concrete containing standard aggregates. However, from fatigue theory $[20,21]$, a stress-strength ratio of less than one indicates that concrete pavement can sustain imposed stresses.

\section{Conclusions and Recommendations}

This study presented a laboratory testing results of eight marginal aggregates and two standard aggregates. The physical properties of aggregates were first determined and concrete was produced from them. Marginal aggregates were found to have higher fines, absorption, soundness loss, micro-Deval abrasion loss, LA abrasion loss and lower specific gravity and unit weight when compared with standard aggregates. Also, from fresh concrete properties, it can be concluded that when properly designed, concrete produced from marginal aggregates can have similar workability and air content as concrete containing standard aggregates. The compressive strength, splitting tensile, flexural strength and modulus of elasticity of concrete containing marginal aggregates were determined and found to be generally lower than concrete containing standard aggregates. 
Table 10 Computed maximum stresses and stress-strength ratios.

\begin{tabular}{|c|c|c|c|c|c|c|c|c|c|}
\hline \multirow[b]{2}{*}{$\begin{array}{l}\text { Aggregate } \\
\text { I.D. }\end{array}$} & \multirow[b]{2}{*}{$\begin{array}{l}\text { Poisson's } \\
\text { ratio }\end{array}$} & \multicolumn{4}{|c|}{ Mean 28-day } & \multicolumn{2}{|c|}{ Computed stress (MPa) } & \multicolumn{2}{|c|}{ Stress ratio } \\
\hline & & $\begin{array}{l}\text { Water } \\
\text { saturated CTE } \\
\text { (coefficient of } \\
\text { thermal } \\
\text { expansion) } \\
\left(10^{-6} /{ }^{\circ} \mathrm{F}\right)\end{array}$ & $\begin{array}{l}\text { Compressive } \\
\text { strength } \\
(\mathrm{MPa})\end{array}$ & $\begin{array}{l}\text { Modulus of } \\
\text { elasticity } \\
(\mathrm{GPa})\end{array}$ & $\begin{array}{l}\text { Modulus of } \\
\text { rapture } \\
(\mathrm{MPa})\end{array}$ & Corner & Middle edge & Corner & $\begin{array}{l}\text { Middle } \\
\text { edge }\end{array}$ \\
\hline \multicolumn{10}{|c|}{ Temperature differential $=+6.67^{\circ} \mathrm{C}$} \\
\hline S1 & 0.24 & 7.92 & 32.54 & 28.34 & 4.62 & 2.34 & 2.52 & 0.51 & 0.55 \\
\hline S2 & 0.27 & 7.67 & 31.65 & 27.19 & 4.52 & 2.30 & 2.43 & 0.51 & 0.54 \\
\hline S3 & 0.25 & 8.83 & 32.06 & 27.62 & 4.65 & 2.39 & 2.63 & 0.51 & 0.56 \\
\hline S4 & 0.26 & 8.96 & 29.65 & 25.70 & 4.31 & 2.40 & 2.54 & 0.56 & 0.59 \\
\hline S5 & 0.22 & 10.70 & 26.27 & 22.68 & 3.93 & 2.43 & 2.56 & 0.62 & 0.65 \\
\hline S6 & 0.27 & 9.96 & 25.03 & 22.45 & 3.72 & 2.39 & 2.48 & 0.64 & 0.66 \\
\hline S7 & 0.27 & 7.59 & 23.99 & 22.75 & 3.69 & 2.14 & 2.19 & 0.58 & 0.59 \\
\hline S8 & 0.25 & 9.60 & 28.68 & 25.51 & 4.48 & 2.40 & 2.54 & 0.54 & 0.57 \\
\hline S9 & 0.22 & 9.09 & 19.03 & 20.95 & 3.52 & 2.23 & 2.30 & 0.64 & 0.65 \\
\hline $\mathrm{S} 10$ & 0.25 & 8.82 & 17.17 & 18.15 & 2.83 & 2.05 & 2.03 & 0.72 & 0.72 \\
\hline \multicolumn{10}{|c|}{ Temperature differential $=-6.67{ }^{\circ} \mathrm{C}$} \\
\hline S1 & 0.24 & 7.92 & 32.54 & 28.34 & 4.62 & 1.11 & 1.22 & 0.24 & 0.26 \\
\hline $\mathrm{S} 2$ & 0.27 & 7.67 & 31.65 & 27.19 & 4.52 & 2.30 & 2.43 & 0.51 & 0.54 \\
\hline S3 & 0.25 & 8.83 & 32.06 & 27.62 & 4.65 & 2.39 & 2.63 & 0.51 & 0.56 \\
\hline S4 & 0.26 & 8.96 & 29.65 & 25.70 & 4.31 & 2.40 & 2.54 & 0.56 & 0.59 \\
\hline S5 & 0.22 & 10.70 & 26.27 & 22.68 & 3.93 & 1.71 & 1.61 & 0.44 & 0.41 \\
\hline S6 & 0.27 & 9.96 & 25.03 & 22.45 & 3.72 & 1.66 & 1.56 & 0.45 & 0.42 \\
\hline S7 & 0.27 & 7.59 & 23.99 & 22.75 & 3.69 & 1.30 & 1.20 & 0.35 & 0.33 \\
\hline S8 & 0.25 & 9.60 & 28.68 & 25.51 & 4.48 & 1.65 & 1.54 & 0.37 & 0.34 \\
\hline S9 & 0.22 & 9.09 & 19.03 & 20.95 & 3.52 & 1.45 & 1.35 & 0.41 & 0.38 \\
\hline $\mathrm{S} 10$ & 0.25 & 8.82 & 17.17 & 18.15 & 2.83 & 1.22 & 1.14 & 0.43 & 0.40 \\
\hline \multicolumn{10}{|c|}{ Temperature differential $=0^{\circ} \mathrm{C}$} \\
\hline S1 & 0.24 & 7.92 & 32.54 & 28.34 & 4.62 & 1.11 & 1.22 & 0.24 & 0.26 \\
\hline S2 & 0.27 & 7.67 & 31.65 & 27.19 & 4.52 & 1.11 & 1.22 & 0.25 & 0.27 \\
\hline $\mathrm{S} 3$ & 0.25 & 8.83 & 32.06 & 27.62 & 4.65 & 1.10 & 1.21 & 0.24 & 0.26 \\
\hline S4 & 0.26 & 8.96 & 29.65 & 25.70 & 4.31 & 1.09 & 1.20 & 0.25 & 0.28 \\
\hline S5 & 0.22 & 10.70 & 26.27 & 22.68 & 3.93 & 1.03 & 1.14 & 0.26 & 0.29 \\
\hline S6 & 0.27 & 9.96 & 25.03 & 22.45 & 3.72 & 1.05 & 1.16 & 0.28 & 0.31 \\
\hline S7 & 0.27 & 7.59 & 23.99 & 22.75 & 3.69 & 1.06 & 1.17 & 0.29 & 0.32 \\
\hline S8 & 0.25 & 9.60 & 28.68 & 25.51 & 4.48 & 1.08 & 1.19 & 0.24 & 0.27 \\
\hline S9 & 0.22 & 9.09 & 19.03 & 20.95 & 3.52 & 1.01 & 1.12 & 0.29 & 0.32 \\
\hline S10 & 0.25 & 8.82 & 17.17 & 18.15 & 2.83 & 0.99 & 1.09 & 0.35 & 0.39 \\
\hline
\end{tabular}

The hardened properties of concrete were inputted in an FEACONS IV to determine critical stress in a typical concrete pavement in Florida. The ratio between the computed critical stresses obtained from FEACONS IV to the modulus of rupture (strength) of concrete was obtained and used as evaluation criterion for potential performance of concrete pavement.
It was found that, critical stress-strength ratio of concrete containing marginal aggregates was higher than that of concrete containing standard aggregates. Thus, concrete containing marginal aggregates will perform poorer than concrete containing standard aggregating this. Notwithstanding, it was found that all critical stress to strength ratios of concrete containing 


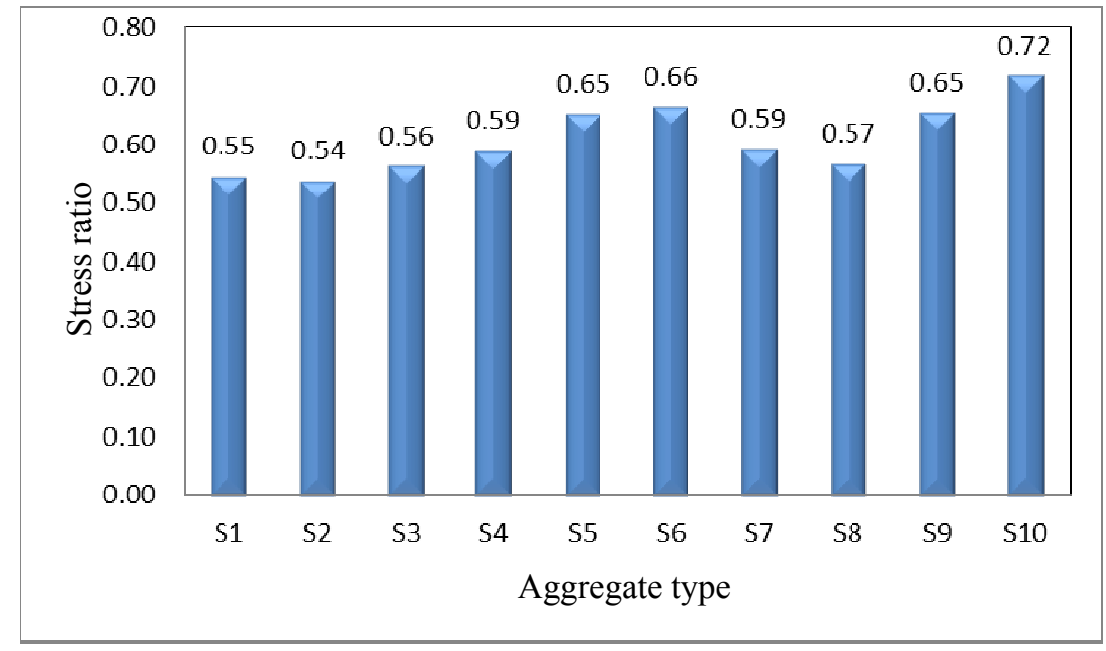

Fig. 5 Plot of the maximum stress to strength ratio vs. aggregate type.

marginal aggregates were less than one. Thus, concrete pavement containing marginal aggregates can sustain imposed stresses. From the forgoing, it can be concluded that when properly designed, concrete containing marginal aggregates can be used successfully as aggregates in concrete pavements.

Therefore, it is recommended that a further study on improving properties of concrete made from these marginal aggregates should be conducted. There is also a need to verify key properties of marginal aggregates that affect properties of concrete in which they are used.

\section{Acknowledgments}

This research will not have come to a successful completion without the assistance of the personnel of FDOT, the researchers are grateful for their assistance. Special thanks go to John Shoucairfor for his leadership and unfettered support. The researchers are also appreciative to all aggregate suppliers who donated their materials for the study.

\section{References}

[1] K.P. Mehta, J.M.P. Monteiro, Concrete Microstructure, Properties and Materials (3rd ed.), McGraw-Hill, New York, 2006.

[2] B. Majumder, A. Das, B. Pandey, Cement treated marginal aggregates for roads, Journal of Materials in Civil Engineering 11 (3) (1999) 257-265.
[3] C. Hazaree, H. Ceylan, High volume fly ash concrete for pavement applications with gap graded aggregates: Marginal and fine sands, in: Proceedings of Airfield and Highway Pavement, USA, 2006, pp. 528-542.

[4] M.N. Haque, M.A. Ward, Marginal materials in roller compacted concrete for pavement construction, ACI (American Concrete Institute) Materials Journal 83 (4) (1986) 674-679.

[5] ASTM C 136, Standard Test Method for Sieve Analysis of Fine and Coarse Aggregates, ASTM International, West Conshohocken, 2011.

[6] ASTM C 117, Standard Test Method for Materials Finer than 75- $\mu \mathrm{m}$ (No. 200) Sieve in Mineral Aggregates, ASTM International, West Conshohocken, 2011.

[7] ASTM C 33, Standard Specification for Concrete Aggregates, ASTM International, West Conshohocken, 2011.

[8] ASTM C 127, Standard Test Method for Density, Relative Density (Specific Gravity), and Absorption of Coarse Aggregate, ASTM International, West Conshohocken, 2011.

[9] AASHTO T 19M/T19-09, Standard Method of Test for Bulk Density (Unit Weight) and Voids in Aggregate, American Association of State Highway and Transportation Officials, 2009.

[10] AASHTO T 96-02, Standard Test Method for Resistance to Degradation of Small-Size Coarse Aggregates by Abrasion and Impact in the Los Angeles Machine, American Association of State Highway and Transportation Officials, 2010.

[11] AASHTO T 327-09, Standard Test Method for Resistance of Coarse Aggregate to Degradation by Abrasion in the Micro-Deval Apparatus, American Association of State Highway and Transportation Officials, 2009.

[12] AASHTO T 104-99, Standard Test Method for Soundness 
of Aggregate by Use of Sodium Sulfate or Magnesium Sulfate, American Association of State Highway and Transportation Officials, 2007.

[13] FDOT, Standard Specifications for Road and Bridge Construction 2010 [Online], ftp://ftp.dot.state.fl.us/LTS/ CO/Specifications/SpecBook/2010Book/2010Master.pdf (accessed Nov. 2, 2011).

[14] ACI 221 R-96, Guide for Use of Normal Weight and Heavyweight Aggregates in Concrete, ACI Committee, 2001.

[15] J.M. Shilstone, Concrete mixture optimization, Concrete International: Design and Construction 12 (6) (1990) 33-39.

[16] J.M. Shilstone Sr., J.M. Shilstone Jr., Performance-Based concrete mixtures and specifications for today, Concrete International 24 (2) (2002) 80-83.
[17] AASHTO T 85-09, Standard Test Method for Specific Gravity and Absorption of Fine Aggregate, American Association of State Highway and Transportation Officials, 2008.

[18] ASTM C 494/C 494M, Standard Specification for Chemical Admixtures for Concrete, ASTM International, West Conshohocken, 2011.

[19] ASTM C 192/C 192M, Standard Practice for Making and Curing Concrete Test Specimens in the Laboratory, ASTM International, West Conshohocken, 2011.

[20] P.X. Shi, F.T. Fwa, A.S. Tan, Flexural fatigue strength of plain concrete, American Concrete Institute, Materials Journal 90 (5) (1993) 434-440.

[21] T.T.C. Hsu, Fatigue of plain concrete, ACI Journal 78 (4) (1981) 292-304. 